\title{
Portuguese Experience With IFRS Adoption As Perceived By Auditors
}

\author{
Ana Paula Silva ${ }^{1}$, Alexandra Fontes ${ }^{2}$, Adelaide Martins ${ }^{3}$
}

Submitted: 12.07.2019. Accepted: 3.04.2020

\section{Abstract}

Purpose: Drawing on the experience of adoption of a model based on the International Financial Reporting Standards (IFRS) by Portuguese non-financial unlisted companies in 2010, called Sistema de Normalização Contabilística (SNC), this paper explores auditors' perceptions regarding dimensions of relevance and suitability of the new accounting model to the Portuguese setting, major problems encountered, and the main engendered benefits.

Methodology: An interpretative approach based on qualitative research methods was adopted, in which sixteen interviews with statutory auditors were conducted from a vantage point in 2017, seven years after the formal implementation of the IFRS-based model.

Findings: Evidence suggests enduring problems but mostly a significant level of legitimation and institutionalization of the IFRS-based model: (i) the perceived motivations for SNC adoption are a good fit with the theoretically acknowledged motivations underlying accounting convergence; (ii) the principle-based standards and the fair value were largely perceived favorably; and (iii) the IFRS-based model brought about a number of benefits as expected ex ante.

Implications: Findings shed light on the potential of the IFRS model to conform to countries whose accounting systems are remarkably disparate - as it was in Portugal - and offer an agenda for regulators and local and international policymakers.

Originality and value: This study contributes to the accounting literature on IFRS adoption by providing empirical evidence from a European country that posited an a priori adverse context.

Keywords: IFRS adoption, institutionalization, legitimation, perceptions

JEL: M40

Escola Superior de Ciências Empresariais, Instituto Politécnico de Viana do Castelo, Av. Pinto da Mota, 4930-600 Valença, Portugal and CEOS.PP - Centre for Organizational and Social Sciences of Porto Polytechnic, Porto, Portugal, e-mail: apaulasilva@esce.ipvc.pt, https:// orcid.org/0000-0003-0412-4572.

2 Escola Superior de Tecnologia e Gestão, Instituto Politécnico de Viana do Castelo, Viana do Castelo, Portugal and Research on Economics, Management and Information Technologies REMIT, Porto, Portugal, afontes@estg.ipvc.pt.

3 University Portucalense, Research on Economics, Management and Information Technologies - REMIT, Porto, Portugal and University of Minho, Braga, Portugal adelaidem@upt.pt. 


\section{Introduction}

The diversity of accounting systems around the world bears economic consequences to the interpretation of financial reporting at the international level and, hence, impacts the consolidation of business affairs. Therefore, a number of international organizations have started the process of the harmonization of accounting standards to promote the transparency and comparability of financial information, which culminated in the International Financial Reporting Standards - IFRS (Dyląg and Kucharczyk, 2010); Shima and Yang, 2012). Seeking this accounting harmonization, the Portuguese Accounting Standards Board - known by its initials as Comissão de Normalização Contabilística (CNC) - developed an IFRS-based accounting model for compulsory adoption by Portuguese non-financial unlisted companies from January 1, 2010, called Sistema de Normalização Contabilística (SNC).

Accounting systems are shaped by economic and political forces; hence the pros and cons of the IFRS are quite conjectural (Ball, 2006). Entities are not just passively constrained by external pressures and expectations (Oliver, 1991). They have interests, capacities, and power that influence their choices (DiMaggio, 1988). The neo-institutional theory explains the interaction between organizations and their wider social environment and focuses on the role of the environment in shaping institutional practices (Albu, Albu and Alexander, 2014; Dillard, Rigsby and Goodman, 2004). A whole accounting revolution happened in Portugal as the new model (SNC) with Anglo-Saxon characteristics implied an abrupt departure from the prior accounting regime, which the international community classified as the Continental Model.

The IFRS adoption is a great breakthrough, whose worldwide effects are still somewhat uncertain (Ball, 2016). Organizational interests and actions are important for IFRS implementation, and more empirical studies are still needed (Albu et al., 2014; Albu, Albu and Gray, 2020). Moreover, countries are not homogeneous in terms of accounting practices (Dillard et al., 2004). Ball (2006, p. 5) draws attention to the inevitable substantial differences among countries in the implementation of the IFRS and the risk of being concealed by "a veneer of uniformity." To obtain a deep understanding of the accounting change process from a code-law institutional logic to a common-law institutional logic, the Portuguese case study was under scrutiny following an interpretative and qualitative approach. From the perspective of 2017, seven years after the formal implementation of the IFRS-based model, we conducted sixteen detailed interviews with statutory auditors (henceforth "auditors") on their perceptions regarding dimensions of relevance and suitability of the IFRS-based model in the Portuguese setting, major difficulties, and engendered benefits. 
Evidence suggests a significant level of legitimation and institutionalization of SNC. The motivations for SNC adoption are a good fit with the theoretically acknowledged motivations underlying accounting convergence. The two major innovations introduced in the Portuguese accounting system by the IFRS model - principle-based standards and fair value - were largely perceived favorably. Moreover, evidence suggests that SNC resembles the IFRS model at least close enough to have brought about a number of benefits that - according to the literature - would result from the application of such an accounting model: contextual benefits at country and business levels, operational benefits, and benefits at the level of statutory auditors' profession. Despite all these encouraging evidence toward the success of the adoption process of SNC in Portugal, the process was not exempt from early difficulties, with some of them still ongoing, such as those related to fair value implementation and Notes preparation.

The next section summarizes the relevant literature. After describing the research method, the major empirical findings are reported. The article concludes with a discussion of the academic and practical implications of the study and suggestions for future research.

\section{Literature Review}

\section{Institutional Theory}

Institutional theory has become the dominant theoretical perspective in accounting research (Dillard et al., 2004), and has been applied to explain some form of change in accounting systems (Deephouse et al., 2017). Institutional theorists significantly contributed to a better understanding of the relationship between organizational structures and practices and the institutional environment in which organizations operate (Beckert, 1999). Within the neo-institutional framework, organizations are open systems that operate and are embodied in a social framework of institutional rules, norms, values, and beliefs that shape their behaviors and with which they must conform to legitimize their existence (DiMaggio and Powell, 1983; Meyer and Rowan, 1977). Legitimacy is defined as "the perceived appropriateness of an organization to a social system in terms of rules, values, norms, and definitions" (Deephouse et al., 2017, p. 32).

Organizations tend to adopt structures, technologies, techniques, and methods that are valued in their wider social environment in order to create, maintain, and manage legitimacy in the eyes of stakeholders, to receive their continued support, and to secure the resources essential for own survival (Dillard et al., 2004; Ribeiro and Scapens, 
2006). To the extent that the accounting system is both legitimated and legitimizing, it must encompass and represent the rationalities of the social and cultural system (Alawattage and Alsaid, 2018).

Accounting systems and practices constitute organizational rules and routines (Burns and Scapens, 2000). More specifically, from an institutional perspective, accounting systems are inextricably linked to the prevailing rules and norms which structure social and organizational life (Burns and Scapens, 2000). Institutionalization is "the process whereby practices are developed and learned" (Dillard et al., 2004, p. 508), which begins "by encoding where principles are encoded into rules and routines" (Järvenpää and Länsiluoto, 2016, p. 156). This process may be subject to resistance if the rules and routines challenge the prevailing institutions and fail to become institutionalized (Burns and Scapens, 2000; Järvenpää and Länsiluoto, 2016). After enactment, "the production and reproduction of established habits of action and thought" (Burns and Scapens, 2000, p. 6) become "new ways of doing things" (Järvenpää and Länsiluoto, 2016, p. 156).

The effects of fields on homogenizing organizations through isomorphic pressures were addressed by utilizing coercive, mimetic, and normative pressures identified by DiMaggio and Powell (1983). Coercive isomorphism results from both formal and informal pressures exerted on organizations by other actors on which they rely and by cultural expectations of the society within which they are located. In turn, mimetic isomorphism occurs under environment uncertainty, when organizations model themselves on other actors, and when normative isomorphism stems primarily from professionalization. The concept of isomorphism results from the idea that organizations compete for political power and legitimacy (Albu et al., 2014) and can be used to reflect intrinsic benefits' components of the perceived value of IFRS and the new accounting model.

However, organizational fields are increasingly heterogeneous, while organizations are not unitary and do not make univocal decisions. They are complex and pluralistic entities composed of various groups with different values, goals, and interests that may respond differently to heterogeneity (Kraatz and Block, 2017). Oliver's (1991) seminal work already suggested that organizations could respond strategically to institutional pressures. The author posits that, when an organization foresees that conformity to institutional pressures will result in economic or legitimacy benefits, it will be more willing to acquiesce to external pressures. In contrast, when organizations anticipate that conformity will result in low legitimacy and economic benefits, they will possibly adopt more active resistance strategies (Oliver,1991). 


\section{The Implementation of IFRS in the Portuguese Context: A Paradigm Shift}

Until 2010, Portuguese organizations had their values and accounting practices anchored on a code-law logic that has shaped their practice over the years, deeply linked to rules of conduct, governed by the concepts of justice and morality, and characterized by detailed regulation (Ding et al., 2007). The implementation of a new accounting system - the SNC - based on the IFRS required a considerable adjustment effort to move from a code-law institutional logic to a common-law institutional logic. The new accounting system based on principles presents great differences regarding the issues of measurement and disclosure of financial information, representing a complete change of philosophy, which places immense responsibility on professional judgment (Caria and Rodrigues, 2014).

According to Carmona and Trombetta (2008), the IFRS already have a high level of acceptance and global implementation, both in countries whose accounting systems embody the rule-based Continental Model and in those countries that embrace the principles-based Anglo-Saxon Model. However, the adoption of the same accounting methods and rules is a too simplistic solution to deal with a set of fundamental differences between the various countries on many levels (Shil and Pramanik, 2009). Empirical evidence shows that at least some of the features of the previous model are still noticeable (Ball, 2016; Caria and Rodrigues, 2014). Guerreiro, Rodrigues, and Craig (2012) argue that the adoption of an accounting system based on an Anglo-Saxon institutionalist logic and focused on a principle-based approach will only be possible if it is accompanied by a gradual transformation of the structures of legitimation in the social environment, whose agents are the Portuguese State, individual organizations, and accounting professionals.

Many countries noted that the IFRS are too complicated and expensive for small and medium-sized enterprises (SMEs), especially the standards dealing with financial instruments, fair value accounting, and impairment (Rodrigues and Craig, 2007). The adoption of uniform rules does not lead to uniform reporting behavior by itself (Ball, 2016). Christensen et al. (2015) argue that reporting incentives dominate accounting standards in determining accounting quality, and it is unwarranted to infer that the IFRS per se improve accounting quality. Hence, Ball (2016) claims that while a uniform implementation of the IFRS is a precondition to reap many of the benefits credited to its adoption, it is unlikely that countries will achieve such a uniformity given the failure to create required enforcement mechanisms, among other factors. 
Rodrigues and Craig (2007) suggest that international accounting standards are chosen not just on efficiency grounds, but often to improve the reputation of an organization for being rational, modern, responsible, and legally compliant. Guerreiro et al. (2012) claim that organizations assess the net benefits of change after considering the legitimacy they attain with IFRS, but also the consistency of IFRS with their goals and institutional context. The authors argue that the predisposition of companies to adopt IFRS is not a blind response to institutional pressures, but rather the result of the inherent nature and importance of such institutional pressures.

\section{Research Method}

To seek a deep understanding of the accounting change process from a code-law institutional logic to a common-law institutional logic, we scrutinized the Portuguese case study following an interpretative approach based on qualitative research methods. The face-to-face interview was the selected data collection instrument. The interview script was structured though flexible, containing mostly open-ended questions. The advantages of such a structured script include the possibility to keep some control over its progress and contents, and the potential for answers' comparison. A major concern throughout the whole interviewing process was to refrain from influencing interviewees' responses. Thus, spontaneous answers were invariably invited and privileged during analysis. Personal contact and the flow of a natural conversation - by reordering questions as appropriate - put interviewees at ease to express their true perceptions (Mahama and Khalifa, 2017). Sixteen interviews were conducted between May and November 2017, and they were one and a half hours long on average. The sample size was determined by saturation considerations. Interviewees included 12 statutory auditors at Portuguese-owned auditing firms and four statutory auditors at multinational auditing firms. Auditors have been used in IFRS studies because of their extensive IFRS knowledge, awareness of the national and international contexts, and the opportunity they provided to access the experience of a large number of companies (Albu et al., 2020). Similarly to our research, other studies of IFRS adoption are solely based on auditors' perceptions (e.g. Albu et al., 2020; Nurunnabi, 2017). The study sample exhibits intentionally homogeneous features (Ellis, 2017) as interviewees' choice was driven by considerations of the level of accounting and auditing knowledge. As a result, 94\% (15 out of 16) of the interviewed auditors had more than 15 years of practical auditing experience, all of them held at least a bachelor's degree and passed highly demanding professional entry exams. Furthermore, the accounting supervisory role played by this professional group positions it well to provide rich insights on the phenomenon under scrutiny. All interviews were recorded and fully transcribed prior to analysis. 


\section{Empirical Evidence}

To support the reader in following our narrative, Table 1 summarizes perceptions of interviewed auditors regarding the adoption of an IFRS-based model in Portugal.

Table 1. Perceptions of the IFRS-based model.

\begin{tabular}{|c|c|c|c|c|c|}
\hline \multicolumn{2}{|c|}{ Agree } & \multicolumn{2}{|c|}{$\begin{array}{l}\text { Rather agree / } \\
\text { Undecided }\end{array}$} & \multicolumn{2}{|c|}{ Disagree } \\
\hline$=1$ & $\%$ & $n=16$ & $\%$ & $\mathrm{n}=16$ & $\%$ \\
\hline
\end{tabular}

Dimensions of relevance and suitability

- Relevance for and suitability to the Portuguese setting

- Relevance for and suitability to unlisted non-financial firms

- Relevance by type of enterprise:

- Larger companies

- Internationalized companies

- Companies with widespread ownership

- Adjustments to the Portuguese setting

Major innovations

- Principle-based standards

- Fair-value

\begin{tabular}{r|r|r|r|r|r|}
\hline 5 & 31.00 & 9 & 56.50 & 2 & 12.50 \\
\hline 10 & 62.50 & 0 & 0 & 6 & 37.50 \\
\hline 15 & 93.75 & 0 & 0 & 1 & 6.25 \\
\hline 12 & 75.00 & 1 & 6.25 & 3 & 18.75 \\
\hline 12 & 75.00 & 2 & 12.50 & 2 & 12.50 \\
\hline 13 & 81.25 & 2 & 12.50 & 1 & 6.25 \\
\hline & & & & & \\
\hline 14 & 87.50 & 0 & 0 & 2 & 12.50 \\
\hline 13 & 81.25 & 0 & 0 & 3 & 18.75 \\
\hline & & & & & \\
\hline 9 & & & & & \\
\hline 15 & 96.25 & 0 & 0 & 7 & 43.75 \\
\hline 13 & 50.00 & 6 & 37.50 & 2 & 12.50 \\
\hline 10 & 81.25 & 0 & 0 & 3 & 18.75 \\
\hline 10 & 62.50 & 3 & 18.75 & 3 & 18.75 \\
\hline & & 2 & 12.50 & 4 & 25.00 \\
\hline
\end{tabular}

\section{Contextual benefits}

- At the country level:

- Foreign investment attraction

- National legitimacy

- Accounting profession legitimacy

- At the business level:

- Improved reputation

- Internationalization

- Improved capital access

$10 \quad 62.50$

Operational benefits - accounting information

- Information usefulness

- Comparability over time

- Comparability between national companies

- International comparability

- Comprehensibility of financial statements

- Contents of financial statements

- Reliability and credibility of accounting information

\begin{tabular}{|r|r|r|r|r|r|}
\hline 16 & 100.0 & 0 & 0 & 0 & 0 \\
\hline 10 & 62.50 & 6 & 37.50 & 0 & 0 \\
\hline 11 & 68.75 & 2 & 12.50 & 3 & 18.75 \\
\hline 13 & 81.25 & 3 & 18.75 & 0 & 0 \\
\hline 10 & 62.50 & 2 & 12.50 & 4 & 25.00 \\
\hline 11 & 68.75 & 2 & 12.50 & 3 & 18.75 \\
\hline 12 & 75.00 & 2 & 12.50 & 2 & 12.50 \\
\hline
\end{tabular}


Impact on the profession of statutory

auditing

- Overall impact

- Multidimensional impact:

- Quality of work

- Celerity in the accomplishment of the tasks

- Reputation and visibility of work

- Responsibilities

\begin{tabular}{|c|c|c|c|c|c|}
\hline 1 & 68.75 & 5 & 31.25 & 0 & 0 \\
\hline 10 & 62.50 & 6 & 37.50 & 0 & 0 \\
\hline 0 & 0 & 8 & 50.00 & 8 & 50.00 \\
\hline & 75.00 & 4 & 25.00 & 0 & \\
\hline 7 & 43.75 & 7 & 43.75 & 2 & 12.50 \\
\hline
\end{tabular}

Source: own elaboration.

Importantly, most interviewees ( $\mathrm{n}=14 ; 88 \%)$ perceived the IFRS-based model to be at least reasonably relevant to or suitable for the Portuguese setting. When freely expressing themselves about this theme, they most frequently mentioned "harmonization," "comparability," "globalization," and "standardization," thus providing good support for the acclaimed reasons that legitimate international accounting convergence (e.g. Shima and Yang, 2012). This may be seen in statements such as the following: "The aim of SNC adoption should have been international harmonization in terms of recognition, measurement, presentation, and disclosure procedures because nowadays international comparability is a key issue in accountability" (A for "auditor," no. 1); "harmonization is an advantage because it favors international trade" (A 15). Internationalization was largely perceived as a contextual benefit at the business level from IFRS adoption ( $\mathrm{n}=10 ; 63 \%)$, and international comparability between companies was also perceived as its significant operational benefit $(\mathrm{n}=13$; $81 \%)$. In the words of auditor 15, "Firms were able to strike up more partnerships at the international level."

Other arguments in favor of the relevance and suitability of the IFRS-based model to the Portuguese environment reflected on the taken-for-granted credibility of the IFRS favoring international credibility of adopting counties, both in terms of commercial relations and capital markets, consistently along with the legitimacy postulate, thus reinforcing the arguments of institutional theorists (e.g., Dillard et al., 2004; DiMaggio and Powell, 1983; Oliver, 1991). This is demonstrated by such statements as the following:

despite the awareness that the IFRS were tailored to capital markets' investors - being quite a misfit with business structures mostly composed of SMEs as it is Portugal's, with many of these firms lacking the administrative and managerial capacity to apply such standards - a set of institutions and their experts decided to push businesses to evolve through the compulsory adoption of standards of acclaimed superior quality and accuracy (A 15). 
The need to bring the Portuguese accounting legislation in line with the EU accounting Directives and Regulations, in particular with Regulation (EC) no. 1606/2002, pushed CNC to conceive an accounting system in line with the high-quality standards already accepted in many countries and jurisdictions (A 6).

Corroborating the model by Dillard et al. (2004), combined with the three types of isomorphism of DiMaggio and Powell (1983), one may conclude this legal obligation decided at the economic and political level is a form of coercive isomorphism, because it results from external pressures and is an instrument of practices legitimation (Guerreiro et al., 2012), but also a mechanism of domination (Dillard et al., 2004). In our study, the most widely acknowledged benefit from the adoption of the IFRS-based model was national legitimacy ( $\mathrm{n}=15 ; 94 \%)$, followed by improved business reputation $(\mathrm{n}=13 ; 81 \%)$. By adopting an independent, worldwide renowned accounting model, Portugal harmonized its accounting practices with the rest of the world and the EU in particular, which resulted in social acceptance by other countries (A 4, 5, 8, 11, 16). This evidence is consistent with the institutional isomorphism described by DiMaggio and Powell (1983). In the words of the auditors, "The adoption of an IFRS-based model improves the country's rating and investors' perception" (A 4); "As a result of an improved country's image, capitalists could access credible and high-value financial information for investments" (A 16); "Companies who employ such an accounting model [IFRS-based model] show a concern with 'doing well,' with providing a true and fair view of their financial and economic position” (A 4). By emphasizing the comprehensibility of financial statements, SNC helps to build up a company's image and may facilitate some businesses (A 2, 13). Another perceived benefit of the IFRS' model was that "it encompasses a set of standards tailored to handle specific situations, to which other models do not respond, such as that of biological assets and environmental matters" (A 6).

On investigating how much interviewees perceived the IFRS-based model to be more relevant to certain types of business, a dominant view emerged of greater disclosure and enhanced reliability perceived as the major features of financial statements prepared in accordance with the IFRS. Specifically, reliability and credibility of accounting information were mostly perceived to have been enhanced by the implementation of SNC ( $n=12 ; 75 \%)$. Interviewees linked this perception with a claimed better fit of the new accounting model with larger internationalized companies with widespread ownership. Besides benefiting from enough administrative resources to prepare all required disclosures - and unlike smaller firms - larger firms, particularly, need to present a true and fair view to investors and managers so as to minimize decision-making uncertainty. In the same line, financial statements are an important control mechanism 
for widespread capital holders, who therefore welcome the greater disclosure and enhanced reliability under the IFRS. Likewise, increased transparency fosters investors' confidence, thus facilitating investment attraction. These were the grounds behind two interviewees' perception of a misfit of the IFRS-based model with the Portuguese environment in that it was geared, in the main, to be applied in countries with strong and dynamic capital markets (A 15) and large firms (A 2).

Narrowing down from the national environment to the specific context of (non-financial) unlisted companies, a smaller majority of auditors $(n=10 ; 63 \%)$ consistently perceived the IFRS model to be suitable, while the remaining six auditors disagreed with its suitability by highlighting size-related constraints, namely the "heavy accountability and disproportionate bureaucratic burden squeezing small businesses, lacking the administrative capacity to meet the new accounting model requirements" (A 14). Invariably, the (dominant) favorable perception toward the adequacy of the IFRS-based model at the business level rested on the coexistence of three different standardization levels within SNC: the full set of 28 standards, the simplified standard for small entities, and the even more simplified standard for micro entities. Seeking to please all businesses regardless of dimension, CNC developed three standardization levels, thus playing the role of institutional entrepreneur - in line with Guerreiro et al. (2012) - as it initiated and theorized the process of change by seeking consensus among the various stakeholders, therefore attempting to legitimate the new accounting model. Since its formal adoption in 2010, the SNC is an adaptation of the EU-endorsed IFRS to the Portuguese setting and particularly its small business structure. Further simplifications were implemented in 2016 by the Decree-law no. 98/2015, which transposed the EU Directive 2013/34 that aimed at reducing the administrative burden on SMEs and simplifying financial reporting procedures. These simplifications were mostly perceived favorably. As of 2010, SNC was too demanding in terms of disclosures, and it is currently more adjusted to most enterprises (A 5, 6, 8). The basic principles were harmonized as desired, but normative exigency should take into account the size of Portuguese enterprises (A 8). In the words of interviewee 13:

In Portugal there are around 30 companies that stand out in terms of size and internationalization of their business affairs; thus, while these need an accounting model that offers more information and greater comparability at the international level, the bulk of companies in the Portuguese business landscape need an adjusted, simplified model (A 13).

Disclosure and Notes preparation emerged as important difficulties in the accounting change process. Despite the acknowledgement that Notes are deemed to be the most 
important piece to stakeholders, as they contain much qualitative and quantitative information in a more disaggregated form (A 4, 7, 11), this financial statement is not yet properly done. The Notes is far too descriptive a document, containing too much text, and lacking meaningful contents (A 1, 3, 9, 10, 12, 14, 16): "disclosures are almost standard, copied from competitors' and/or from previous years, with very little adaptation" (A 14). This evidence is consistent with Christensen et al. (2015), who argue that it is unwarranted to infer that the IFRS improve accounting quality per se, and with Rodrigues and Craig's (2017) argument that the IFRS are too complicated and expensive for SMEs in many countries. The earliest difficulty of SNC adoption was resistance to change, as the adoption of the new accounting model involved the internalization and implementation of brand-new concepts and practices (A 3, 10, 12). For example, "for unlisted companies, goodwill is a very difficult concept to grasp, as this sort of companies purchase another business once in a lifetime or, say, every ten years, so they lack the necessary experience” (A 13).

Despite the high level of consensus about the general appropriateness of in-country adjustments ( $\mathrm{n}=13 ; 81 \%$ ), we found a few caveats when further debating the issue with interviewees. First, the coexistence of three normative levels in the Portuguese accounting system - with a simplified standard for small entities and an even further simplified standard for micro entities - was not exempt from criticism. Particularly, it was said to harm the goals of comparability and harmonization underlying accounting convergence. As put by auditor 2, "SNC looks more like a patchwork ... while adoption should be 'tout court' ... and the set of standards should be unique". In Portugal, every simplified norm under SNC is optional and - besides that - any enterprise regardless of size and upon the condition of having accounts certified by a statutory auditor may choose to adopt the EU-endorsed IFRS, rather than SNC, which generates several vertical options. Illustrating the perceived reduced comparability and harmonization by cause of simplified normative, two interviewees mentioned that firms belonging to international groups might adopt the EU-endorsed IFRS, rather than SNC , to achieve the required comparability level underlying their accountability; while two others interviewees argued that image enhancement may be the catalyst to elect EU-endorsed IFRS instead of SNC, mainly among larger enterprises that wish to provide more information to potential investors, thereby differentiating themselves from competitors. Again, this evidence supports the theoretical argument of Oliver (1991) that accounting choices are motivated by anticipated economic or legitimacy benefits. Second, a critical view emerged questioning the arbitrariness underlying the definition of size categories: "What is a small entity? What is a micro entity? The issue of boundaries setup is not easy because countries are different; they face different economic realities" (A 11). This remark conveys Ball's (2006) cautioning about differences among countries 
in IFRS implementation. According to DiMaggio and Powell (1983), the definition of thresholds for the distinction of entities can be considered as a form of normative isomorphism, in which professional associations and respective accounting and auditing professionals exert their capacity to influence the negotiation of limits, legitimized by formal education and knowledge. Third, some interviewees were critical of a too literal translation into the Portuguese language based upon a word-for-word interpretation of international standards ( $\mathrm{n}=4 ; 25 \%)$. Accordingly, a literal translation of concepts results in an awkward, unfamiliar language that is difficult to understand, which may hinder the full adoption of the standards and consequently harm accounting convergence. For example, "impairment was translated into SNC as 'imparidade,' which makes a whole new word in the Portuguese lexicon that gave rise to some discord among professionals" (A 6). This comment illustrates the lasting difficulties that Rodrigues and Craig noted as early as 2007 about impairment. In an even more critical perspective, financial statements became less understandable than under the prior accounting model due to a very technical language based upon literal translations $(A), 9)$. This corroborates the need to consider countries' idiosyncrasies, as far as the IFRS worldwide implementation is concerned. Fourth, the IFRS evolve faster than in-country adjustments, which hampers harmonization $(n=6 ; 38 \%)$. SNC remained unchanged between 2010 and 2015, while in the meantime, IFRS were evolving (A 12, 13, 14). The following statement highlights this point:

When SNC underwent a number of adjustments implemented by the Decree-law no. 98/2015, all changes operated on the IFRS should have been endorsed, and a timetable for periodic reviews of SNC should have been agreed upon; at the moment, no one knows whether SNC is undergoing further updates, and if so, within what time frame (A 13).

There is a risk that, in a few years' time, the Portuguese accounting system will be based on principles that have nothing to do with the IFRS (A 2, 6, 7, 12, 14). In the wording of auditor 12: "It was a process of convergence that is becoming one of divergence." Six of the interviewees (38\%) spontaneously addressed the amortization of goodwill as one example of the remarkable difference between SNC and IFRS. Goodwill is not amortizable under the IFRS, whereas one of the amendments resulting from the Decree-law no. 98/2015 was the implementation of its mandatory amortization over useful life or over a maximum time period of ten years, when useful life is indefinite. As a result, many firms abandoned SNC in favor of the EU-endorsed IFRS (A 3, 12, 14). Some auditors were very critical of this in-county adjustment, arguing that impairment losses depict reality much more faithfully than stipulating at the outset the maximum useful life of ten years that may prove quite a misfit in many instances (A 5, 6, 7). 
Interviewees overlooked the maintenance of a chart of accounts as an in-country adjustment that is a link to the prior continental accounting model; deemed to bring security to accounting practices by functioning as a script or a rigid rule that facilitates procedures. Its suggested inessentiality stands clear from the following comment:

The charter of accounts was kept as a result of the pressure exerted by professionals through the respective associations, being regarded as key technical support for the correct classification of accounting operations; however, the standards themselves contain all the necessary technical guidelines, so that the existence of the chart of accounts shall make no difference in terms of IFRS compliance (A 2).

Despite the IFRS model differing remarkably from the previous Portuguese rule-based accounting model - embedding a prudent measurement approach - an outstanding majority of interviewees supported the principle-based standards ( $\mathrm{n}=14 ; 88 \%$ ) and fair value adoption ( $\mathrm{n}=13$; 81\%). Interviewees' arguments were consistent with the unanimously perceived operational benefit from the IFRS adoption at the level of accounting information, i.e. of information usefulness $(n=16 ; 100 \%)$.

Illustrative quotations of perceptions of principle-based standards are the following: "To act according to principles implies having to decide and take responsibility" (A 2); "Principles make everything more flexible" (A 13); "Under rule-based standards, market players will always come up with new situations unforeseen by such rules, thereby opening the door to big financial scandals; to the contrary, under principle-based standards, there are guiding principles that apply to every situation at hands, therefore acting as a deterrent to financial scandals" (A 7). Nevertheless, a minority of two auditors negatively perceived the principle-based standards by arguing that the rules leave no room for arbitration, as they are tighter, quicker, and easier to implement; moreover, accounting professionals are keen on adhering to the rules, and they are not yet predisposed to act according to the principles.

The dominant argument around fair value as the most appropriate measurement basis was that it brings more security and certainty to measurement, thereby increasing reliability and relevance of financial statements vis-à-vis stakeholders: by better resembling the real value of the company, fair value promotes less risky economic and financial decisions (A 1, 12, 14). Despite mostly welcoming fair value as a measurement basis, auditors highlighted several problems associated with its practical implementation. First, there is poor availability and reliability of market values for the fair value. Second, and related to the former, fair value is difficult to apply because it entails 
a great deal of subjectivity and may be subject to manipulation, which causes resistance to its adoption (A 13, 15). To illustrate this subjectivity, interviewee 13 provided an example of two large cellulose companies in Portugal:

one of them claims it cannot reliably measure the fair value of its eucalyptus plantations and therefore adopts the cost method; the other one adopts fair value and claims it is assigning real value to its forest. If the assets are equal, why the adopted measurement basis is not the same?

Moreover, the fair value is often adopted with a view to manipulating accounts: to leverage financial autonomy or coverage ratios vis-à-vis the bank, therefore not mirroring the real value of a company (A 1, 3, 5, 11). A similar argument was put forth by three interviewees who perceived the IFRS adoption as not resulting in increased comparability between companies, as illustrated by the following statement: "Principle-based standards and the use of fair value may open up more room for manipulation because there are fewer rules and greater subjectivity, therefore causing comparability loss" (A 8). The experts who do evaluations are a related concern. Who are they? Are they professionals? It remains unclear who trains them (A 3, 4, 6, 12, 13, 15). Third, another deterrent to the use of fair value is the unfavorable cost/benefit ratio, particularly critical for the smaller, resource-constrained companies: evaluations entail high costs, which are not paid off by tax benefits $(A, 6,12)$. When reflecting on these problems, a minority of three interviewees criticized the adoption of fair value. Accordingly, the historical cost promotes greater stability, because it represents an amount that has already occurred and is not subject to fluctuation, therefore becoming more reliable and adjusted to accountability, especially among the resource-constrained micro and small entities, which find the adoption of fair value unaffordable (A 11, 15).

Finally, the impact of the IFRS adoption on the profession of statutory auditors was appraised. Outstandingly, none of the interviewees considered the impact had been negative, while the majority $(\mathrm{n}=11 ; 69 \%)$ perceived an overall positive impact. The benefits were more keenly felt in terms of reputation and visibility of auditors' work ( $\mathrm{n}=12 ; 75 \%)$ and in the quality of such work $(\mathrm{n}=10 ; 63 \%)$. Improved visibility was brought about by standards' complexity leading other professionals, notably accountants, to turn to auditors for explanations and help, e.g. when preparing the Notes. Therefore, the auditor assumed a pedagogical role that conveys security and credibility to clients (A 2, 6, 7, 8, 10, 13, 16). This is consistent with Guerreiro et al. (2012), who argue that the adoption of the IFRS-based model demands a gradual transformation of the structures of legitimation in the social environment, whose agents include professionals. Overall, the interviewed auditors acknowledged that the adoption of 
the IFRS-based model brought increased contingency, more responsibility both in terms of preparation of staff members and the work $(n=7 ; 44 \%)$. None of the interviewees perceived the IFRS-based model to favor celerity in the accomplishment of tasks. Unlike the rule-based standards that are of straightforward application, the subjectivity entailed by the IFRS-based model - particularly on the themes requiring professional judgment - becomes very time-consuming (A 1, 3, 4, 5). Therefore, analysis has become more demanding (A 5, 6). Besides, there is a greater deal of financial information and greater disclosure, which requires more time for analysis (A 7, 11, 12).

\section{Conclusion}

By adding an enhanced understanding of the institutional context and its influence on the effects of the IFRS adoption, this research contributes to the accounting literature. It provides empirical evidence from a European country that posited an a priori adverse context to the related accounting change process: Portugal's prior accounting model followed a code-law institutional logic opposite to the IFRS common-law's, it has a small capital market, and its predominant business structure is small-sized and mostly bank-financed. Notwithstanding, encouraging evidence was gathered that might arguably inspire other countries, particularly those with similar traits, to undergo such an accounting change process. This research highlights that the perceived motivations for SNC adoption are a good fit with theoretically acknowledged motivations underlying accounting convergence. Arguably, the similarity between these may be taken as a proxy for the legitimation of the new accounting model. Moreover, two major innovations introduced in the Portuguese accounting system by the IFRS model - principle-based standards and fair value - were largely perceived favorably. Furthermore, in spite of criticisms concerning a set of in-country adaptations, SNC resembles the IFRS model at least close enough to have engendered a number of benefits that - according to the literature - would result from the application of such an accounting model. That is, contextual benefits at country and business levels, operational benefits, and benefits at the level of statutory auditors' profession. Despite the shared view of $94 \%$ of the interviewed statutory auditors that the IFRS-based model is more relevant for larger companies, the issue of size stood out as having been mostly remedied by the establishment of a simplified standard for micro entities, by Decree-law no. 98/2015, and through further simplifications and amendments to the dimension criteria underlying the different standardization levels that coexist within SNC. Yet, there is a challenging view that the coexistence of three size-adjusted norms within SNC makes it "look like a patchwork," thus detracting from the comparability and harmonization precepts, which underlie accounting convergence. 
According to Burns and Scapens (2000), the maintenance of a chart of accounts is an indicator of resistance to the process of change, called "the power of the system." That is, the power of existing institutions that are persuasive and able to withstand the change that is imposed on them. Thankfully, the maintenance of a chart of accounts came out as an overlooked in-country adjustment.

Although the Portuguese adoption process of the IFRS-based model experienced several difficulties - some of them still present, such as those related to fair value implementation and Notes preparation - auditors' perceptions suggest a significant level of legitimation and institutionalization of the new accounting model has been achieved seven years after its adoption. Our findings on the enduring problems associated with the adoption of the IFRS-based model should be of interest to both Portuguese regulators (CNC and the Portuguese Securities Market Commission) and Portuguese professional associations (The Portuguese Certified Accountants Association and the Auditors Association) to the extent that they may inspire them to devise strategies to cope with these issues. International institutions such as the International Accounting Standards Board and the Accounting Regulatory Committee may also consider our findings to improve the future of the international accounting convergence process.

Lastly, while the research of qualitative nature allows for the extraction of richer, deeper insights about the phenomenon under study, we acknowledge that one cannot generalize on our results. Therefore, future research could validate the generalization of our findings on a larger sample. Moreover, scholars could study the perceptions of other professional groups, namely accountants. Statutory auditors are particularly experienced with larger companies, so their perceptions could possibly have been more optimistic than those of external accountants, whose clients are mostly small.

\section{Acknowledgments}

This is an expanded version of a paper entitled "Insights towards IFRS' legitimation and institutionalization based upon perceptions of statutory auditors: the Portuguese case" presented at the 43rd International Scientific Conference on Economic and Social Development, University of Aveiro, Campus Universitario de Santiago, 3810-193 Aveiro, Portugal, July 16, 2019. The authors would like to thank the participants for their comments and suggestions. The authors would also like to express their sincere gratitude to two anonymous referees of the journal for their constructive comments, which have helped to improve this paper. 


\section{References}

Alawattage, C. and Alsaid, L.A. (2018). Accounting and structural reforms: A case study of Egyptian electricity. Critical Perspectives on Accounting, 50, 15-35, https://doi.org/10.1016/j.cpa.2017.09.001.

Albu, C.N., Albu, N. and Alexander, D. (2014). When global accounting standards meet the local context-Insights from an emerging economy. Critical Perspectives on Accounting, 25(6), 489-510, http://dx.doi.org/10.1016/j.cpa.2013.03.005.

Albu, N., Albu, C.N. and Gray, S.J. (2020). Institutional Factors and the Impact of International Financial Reporting Standards: The Central and Eastern European Experience. Accounting Forum, https://doi.org/10.1080/01559982.2019.1701793.

Ball, R. (2006). International Financial Reporting Standards (IFRS): pros and cons for investors. Accounting and Business Review, 36 (Special Issue), 5-27, https://doi.org/10.1080/00014788.2006.9730040.

Ball, R. (2016). IFRS - 10 years later. Accounting and Business Research, 46(5), 545-571, https://doi.org/10.1080/00014788.2016.1182710.

Beckert, J. (1999). Agency, entrepreneurs, and institutional change. The role of strategic choice and institutionalized practices in organizations. Organization studies, 20(5), 777-799, https://doi.org/10.1177/0170840699205004.

Burns, J. and Scapens, R. (2000). Conceptualizing management accounting change: an institutional framework. Management Accounting Research, 11, 3-25, https://doi.org/10.1006/mare.1999.0119.

Carmona, S. and Trombetta, M. (2008). On the global acceptance of IAS/IFRS accounting standards: The logic and implications of the principles-based system. Journal of Accounting and Public Policy, 27(6), 455-461, https://doi.org/10.1016/j.jaccpubpol.2008.09.003.

Caria, A.A. and Rodrigues, L.L. (2014). The evolution of financial accounting in Portugal since the 1960s: A new institutional economics perspective. Accounting History, 19(1-2), 227-254, https://doi.org/10.1177/1032373213511319.

Christensen, H.B., Lee, E., Walker, M. and Zeng, C. (2015). Incentives or standards: What determines accounting quality changes around IFRS adoption? European Accounting Review, 24(1), 31-61, https://doi.org/10.1080/09638180.2015.1009144.

Deephouse, D.L., Bundy, J., Tost, L.P. and Suchman, M.C. (2017). Organizational legitimacy: Six key questions. In: R. Greenwood, C. Oliver, T. Lawrence and R. Meyer (eds.), The Sage Handbook of Organizational Institutionalism (pp. 27-54). Thousand Oaks, CA: Sage.

Dillard, J.F., Rigsby, J.T. and Goodman, C. (2004). The making and remaking of organization context, Duality and the institutionalization process. Accounting Auditing and Accountability Journal, 17(4), 506-542, https://doi.org/10.1108/09513570410554542.

DiMaggio, P.J. (1988). Interest and agency in institutional theory. In: L.J. Zucker (ed.), Institutional patterns and organizations. Culture and environment (pp. 3-21). Cambridge: Ballinger.

DiMaggio, P.J. and Powell, W.W. (1983). The iron cage revisited: Institutional isomorphism and collective rationality in organizational fields. American Sociological Review, 48, 147-160, https://doi.org/10.2307/2095101.

Ding, Y., Hope, O.K., Jeanjean, T. and Stolowy, H. (2007). Differences between domestic accounting standards and IAS: Measurement, determinants and implications. SSRN Electronic Journal, 26(1), 1-38, https://doi.org/10.1016/j.jaccpubpol.2006.11.001.

Dyląg, R. and Kucharczyk, M. (2010). The issue of reporting in small and medium-sized entities (SMEs) in the light of the International Financial Reporting Standard (IFRS) for SME. Journal of Management and Business Administration. Central Europe, 18(6). 
Ellis, P. (2017). Language of research (part 12) - research methodologies: grounded theory. 13(1), 102, https://doi.org/10.1108/eb026919.

Guerreiro, M.S., Rodrigues, L.L. and Craig, R. (2012). Voluntary adoption of International Financial Reporting Standards by large unlisted companies in Portugal-Institutional logics and strategic responses. Accounting, Organizations and Society, 37(7), 482-499, https://doi.org/10.1016/j.aos.2012.05.003.

Järvenpää, M. and Länsiluoto, A. (2016). Collective identity, institutional logic and environmental management accounting change. Journal of Accounting $\&$ Organizational Change, 12(2), 152-176, https://doi.org/10.1108/JAOC-11-2013-0094.

Kraatz, M.S. and Block, E.S. (2017). Institutional Pluralism Revisited. In: R. Greenwood, C. Oliver, T.B. Lawrence and R.E. Meyer (eds.), The Sage handbook of organizational institutionalism. Thousand Oaks, CA: Sage.

Mahama, H. and Khalifa, R. (2017). Field interviews - process and analysis. In: Z. Hoque, L.D., Parker, M.A. Covaleski and K. Haynes (eds.), The Routledge Companion to Qualitative Accounting Research Methods (pp. 321-338). London: Routledge.

Meyer, J.W. and Rowan, B. (1977). Institutional organizations: Formal structure as myth and ceremony. American Journal of Sociology, 83(2), 340-363, https://doi.org/10.1086/226550.

Nurunnabi, M. (2017). Auditors' perceptions of the implementation of International Financial Reporting Standards (IFRS) in a developing country. Journal of Accounting in Emerging Economies, 7(1), 108-133, https://10.1108/JAEE-02-2015-0009.

Oliver, C. (1991). Strategic Responses to Institutional Processes. Academy of Management Review, 16(1), 145-179, https://doi.org/10.5465/amr.1991.4279002.

Ribeiro, J. and Scapens, R. (2006). Institutional Theories in management accounting change - Contributions, issues and paths for development. Qualitative Research in Accounting \& Management, 3(2), 94-111, https://doi.org/10.1108/11766090610670640.

Rodrigues, L.L. and Craig, R. (2007). Assessing international accounting harmonization using Hegelian dialectic, isomorphism and Foucault. Critical Perspectives on Accounting, 18, 739-757, https://doi.org/10.1016/j.cpa.2006.02.007.

Shil, N.C.D., Das, B. and Pramanik, A.K. (2009). Harmonization of Accounting Standards through Internationalization. International Business Research, 2, 194-200.

Shima, K.M. and Yang, D.C. (2012). Factors affecting the adoption of IFRS. International Journal of Business, 17(3), 276-298. 